\title{
The Proposals of Landslide Spatial-Mitigation Strategy in Indonesia; A literature study from the events of 2010-2015
}

\author{
Doni Sastra ${ }^{1}$ and Noor Cholis Idham ${ }^{1, *}$ \\ ${ }^{1}$ Universitas Islam Indonesia, Faculty of civil engineering and planning, Indonesia
}

\begin{abstract}
Increasing phenomena of climate change following by the deformation of the geological surface area of Indonesia cause various disasters such as landslides and floods. During the period of 2008 to 2016, there have been 307 total occurrences destructed many locations in the country with many mitigations have been done according to the type and location of the disaster with some different degree of success. This study is aimed to describe how landslide mitigation related to spatial configuration had been organized in the proposals. A literature study has been done to describe and compare each of the techniques utilized in the cases. The result explains the cause and the typology strategy of landslide mitigation which is divided into two steps, the preliminary and mitigation design. All these steps are finally found to be in close connection to the spatial arrangement which is very useful to decide safety precaution before the event of a landslide.
\end{abstract}

\section{Introduction}

Indonesia is a second prone country to the natural disasters after Bangladesh [1]. As a result of an overcrowded population which needs space for living such as opening new land for farming and the uncontrolled deforestation, greenery is decreasing by $87.0 \%$ from 1950 to 2015 [2]. The impact of global climate change are increasingly noticeable, the high-intense atmosphere temperature causes the phenomena of season-change. The condition of rivers and watersheds are also critically unstable. Furthermore, surrounding the most vulnerable land, ring of fire, are being occupied by millions of population which definitely prone to disaster. It has caused the disaster management becomes more complex and multidimensional [3].

Disaster trends in Indonesia from 2008 to 2016 tend to increase over time. Based on data from the National Disaster Management Agency (BNPB) 95\% of them were meteorological disaster including landslides, floods, tornadoes, extreme weather, and drought [3]. Disasters increased by $17.5 \%$ in 2014, with many landslides 293 in 2013, Landslide in Java are as much as $62.0 \%$, Sumatra $21.2 \%$, Sulawesi $6.7 \%$, and Kalimantan $5.1 \%$. The peak of the rainy season in Indonesia was experiencing hydro meteorological disasters such as "Flood and Landslide", with the case of 307 events in West Java, and

\footnotetext{
* Corresponding author: $965120101 @$ uii.ac.id
} 
followed Central Java with 140 incidents, and East Java with 111 incidents, the victims died and disappeared as many as 622 people. BNPB announced about 40.9 million people are exposed to landslide hazards. In 2017 the occurrence throughout Indonesia reached 576 events. The losses due to the disaster range from 30 trillion rupiah in 2016. Landslide is the movement the slopes that fall / slide toward the foot of the slope due to the control of gravity of the earth [4], slope constituent material is soil or rock [5]. The condition poses a threat to the people affected by the landslide, and the situation may turn into a disaster if it has caused the millions loss of life. To minimize the number of victims and losses, a comprehensive and measurable landslide mitigation plan is needed.

The mitigation plan measures a broad scope such as a prevention step which is various instep. According to CRMS Indonesia, is to understand disaster risk, consider a hazard, exposure, and vulnerability to disasters from a region, also reduce disaster risk, aiming to maintain life and assets [6]. And also RA (Risk Analysis) was introduced in the same manner as $C R M S$, conclude various step, including analysis of vulnerability, and also planning specifically spatial and land use [7]. The key to understanding the risk and vulnerabilities is to contextualize it within the broader perspectives of disaster management, as early mention both CRMS and RA. And the impact of those step implementation was spatial arrangement and change of structure of land [8].

This paper will try to understand the vulnerability of an area to landslides, as well as how to reduce disaster risks, by studying several references to landslide mitigation proposals in Indonesia of 2010-2015. This tendency for understanding vulnerability, need to a considered number of precedence and precondition in cities and urban area, these can contribute to and influence to risk [8]. A qualitative descriptive method is decrypting the method with the secondary data. Typology is chosen to set comparative, as Ching points out, that there is a tendency to group elements in a random position, either based on the cohesiveness of the layers or the visual characteristics it possesses [9]. Typology analysis is divided into 3 phases [10]: (1) Analyze typology by digging from history to find out the initial idea of a composition, or in other words, know the origin or occurrence of an architectural object. (2) Analyze typology by knowing the function of an object. (3) Analyze the typology by finding a simple form of a building through a basic search and basic properties.

\section{Finding and Discussion}

Landslide is a result, of course, it happens because there is a cause. In this segment of research presents the causes of landslides, which are summarized from previous research. Angle Of Slope, An important factor in the process of landslide [11], [12]. The condition is a natural area, hills, mountain rows, non-natural conditions such as making access to roads. In this situation, landslides are often encountered [13], among other causes: stack on slopes, poor drainage, groundwater and slope cuts, very high stockpiles, and steep rock slopes, the above factors are the supporting elements. The major factor is the slope. This is evidenced by the number of incidences on a given slope, slope $>45^{\circ}$ has the highest incidence rate [14].

Land Uses, Plants able to hold rainwater to penetrate the soil for a while, and drainage can prevent saturation of slope material and erosion [15]. In the typology of a region, of course, there are various types of land cover, such as forests, open land, agricultural land and plantations, settlements, roads, etc. How a land function against the risk of landslides. the function of a land to produce a variety of disaster zones, for areas with high-risk zones, will be at risk if there are settlements, rice fields and plantations [16]. The highest percentage of $26.09 \%$ is the rice field in a dry season, second place is garden $19,57 \%$, and settlement area $15,22 \%$ [17]. 
Soil composition determines the potential for landslides, soil regosol from volcanic and regosol is a very sensitive landslide compared to andosol or latosol. Less dense soil type is clay or clay soil with a thickness of more than $2.5 \mathrm{~m}$ and a slope angle of $22,0 \%$, has the potential for landslide especially when it under rains. The soil is susceptible to movement due to being flabby exposed to water and breaking when the temperature is high [18]. In West Java, the dominance of landslide events in the class of tuff volcanic intermediary rocks with 20 events (43.48\%), ash / sand rock and turf Volkan intermediary as much as 8 events (17.39\%) [17], Rainfall, The causes of soil movement and mechanism are well known, while the main trigger is rainfall [17], [19], [20]. With rainfall ranging from 2000 $\mathrm{mm} /$ year, Indonesia is vulnerable to climate catastrophe which is frequently increasing [21].

\subsection{Study Precedents of Landslide Mitigation}

With the goal is the extraction of causes of landslides, disaster mitigation plans, and spatial changes applied from precedent studies

\subsubsection{Proposal for landslide handling on the slopes of toll road Gempol - Pandaan $\mathrm{km}$ 51, Pasuruan, East Java [22]}

Field identification of the slope at the disaster site is about $45^{\circ}$, due to the limited width of land for road construction. The width of the land is not sufficient then the slope very inclined. Soil type identifies that the type of soil around the site is a volcanic sulfate-sized material of brown to reddish-brown sand, this type of soil is mostly loose. There are many rocks, this soil is the original soil. The deep soil can increase the soil mass if the pores in the soil are filled with water so that the slope stability decreases. The easier to pass water (high permeability) then the ability to hold water is smaller so it is not easy to slide. Some seepage flows from the ground at the location around the landslide also occurs seepage through pore holes on the slopes of the highway. The existence of this seepage causes the stability of the slope to decrease. A landslide occurs after rain. This heavy rain causes the pore number in the soil increases, the pore stress weakens the frictional resistance in the soil. Above the landslide, there is a pool or a puddle of water resulting from the flow of rainwater from around the plant and settlements.

The main cause of the occurrence of landslides is a steep slope, triggered by high rainfall. The morphological factors at the lower landslide location of the surrounding area were causing surface water flow to accumulate at the landslide site, forming a puddle. There was a pool on top of the slope and some water dribbled down through the slopes. Land above the landslide point becomes water saturated due to the accumulation of rain water. This pond of rain-water will seep into the ground, thus becoming ballast that increases the thrust and reduces the retaining force, thereby inducing a landslide.

This proposal is a type of research, the location of landslide cases in Randupitu village on Toll road Gempol-Pandaan $\mathrm{km} \mathrm{51.} \mathrm{The} \mathrm{recommendation} \mathrm{according} \mathrm{to} \mathrm{landslide} \mathrm{handling}$ based on the causes of landslides was taken according to SNI 03-1962-1990, countermeasures prevention can be done by controlling seepage water. Efforts to drying or lowering the water in the slope are by controlling the seepage water. The following describes the recommendation for landslide prevention.

1. Build Drainage on The Surface. Water is the trigger of the landslide in this case, and infiltration of water from the surface into the plane of the slope is handling by drainage. Rainwater is stored in the control basin and flowed into the sewer, the anti-infiltration step of the water into the slope.

2. Creating Waterproof Areas. This step anticipates water infiltration in the puddle area, the potential of inundation occurs during periods of high rainfall. With this method, the 
flow of water that passes from the control basin does not seep into the soil and equipped with horizontal drainage to drain water on slopes,

3. Build an underground drain (sub-drain). This step is a further anticipation of water infiltration in the entire area of the slope. With this, the inner pervasive water can be channeled out of the ground through the slopes.

4. Build Drill Pile (Structural). It functions to enlarge the slope support force against the landslide so that the slope stability will increase. Because the slope conditions in the design are steep due to a limited area.
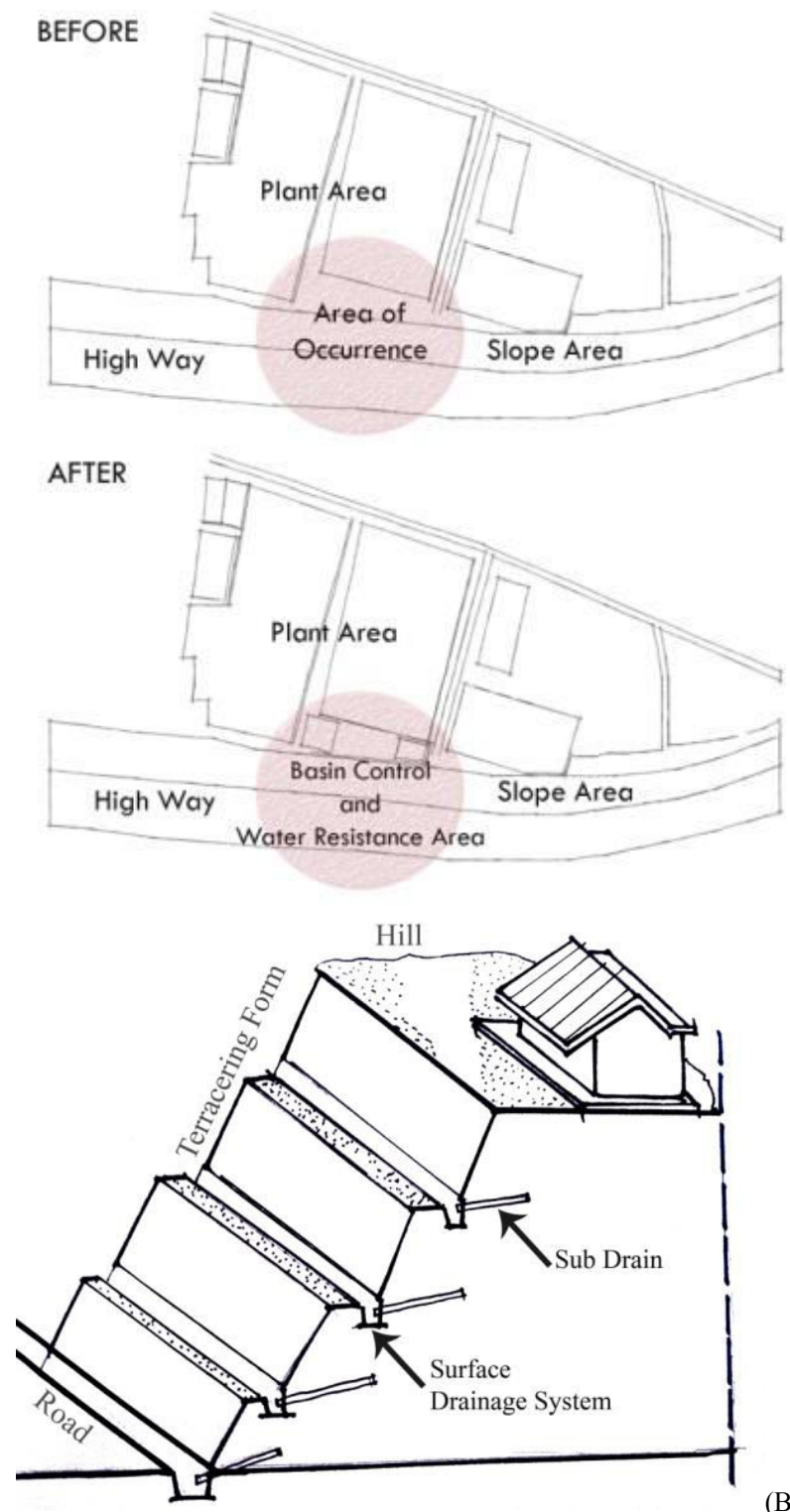

(A)

(B)

Fig. 1. (A) Spatial arrangement proposed by the proposal (redrawn from Hidayat and Subiyantoro, 2015) (B) Sketch of a design proposal for landslide mitigation (redrawn from Hidayat and Subiyantoro, 2015) 
Data on the causes of disasters from the proposal have been described. a comparison between the evidence of this proposal and the factors that caused the landslide mentioned earlier, there are 4 factors that are synchronous with the cause of landslides in precedents. These factors are taken into account in designing landslide mitigation designs as mentioned above. The action that accounted as spatial arrangement on site that prone-area is adding water resistance area to increase the stability of soil, and basin control to minimize the effect of water flow from because of rain from plant and settlement area. The basin control will connect to the sub-drain and surface drainage system.

\subsubsection{Proposal of Starlet Model, Proposed Landslide Mitigation by Approach of Region Genetic Approach (case study: Avalanche Citatah, Padalarang, East Java, 2010)[23]}

The handling of landslide-prone slopes which involving integration between (1) landslide mapping systems and landslide-prone slopes, (2) stability analysis of slopes for early warning and for stabilization, (3) stable slope design simulations, and (4) environmental management with environmental monitoring, involving the role of scientists, government officials, communities [24].

In this case study, however, the Starlet model uses the Regional Genetic Area Approach (SGW). This approach is a system that captures the phenomenon of types of landslides. After connecting with soil moisture variables, the increase in water content leads to decreased cohesion and internal shear angle. All these variables determine the slope safety factor. Based on the calculation of these variables, the area with a soil material with a slope of $26,29^{\circ}$ to $44,28^{0}$ means in beware, to obtain a slope of stable slope $<26.29^{0}$.

According to the steps of this model, the second step is a vital step in the planning, which is to determine the stability of the slope for the landslide mitigation planning process. Get the conclusion from the second step. The following steps are the design of the Starlet model, the proposal for landslide mitigation with the slope management efforts includes:

1. The conservation of the slopes which is unstable with the design of stable slopes by making the steps (terracing).

2. Re-vegetation as a way to control groundwater and rainwater and for strengthening at the foot of the slope. The types of plants grown include tea, naughty children (Duranto erecta), and kajibeling (Sericocalyx criptus). As well as grass on the body of the slope is done to hold rainwater that falls into the body of the slope.

3. Making drainage lining as an effort so that the flowing water does not enter the body of the slope and the slope is not saturated. The drainage system at the foot of the slope serves as a water controller that can emerge from the water supply holes. The drain hole works to drain the water in the body of the slope so that soil water level can be maintained so that the degree of saturation in the body of the slope can be maintained. When the groundwater level rises in the body of the slope, can be controlled by water distribution.

4. Lowering the groundwater surface on the unstable slopes or on any retaining wall, especially at the foot of the slope. The retaining wall at the foot of the slope serves as a reinforcement slope when the load at the top of the slope (which adds a thrust force to the sliding) is still large.

5. Covering the broken slope and avoiding the pools and rice fields at the top of the slopes. 

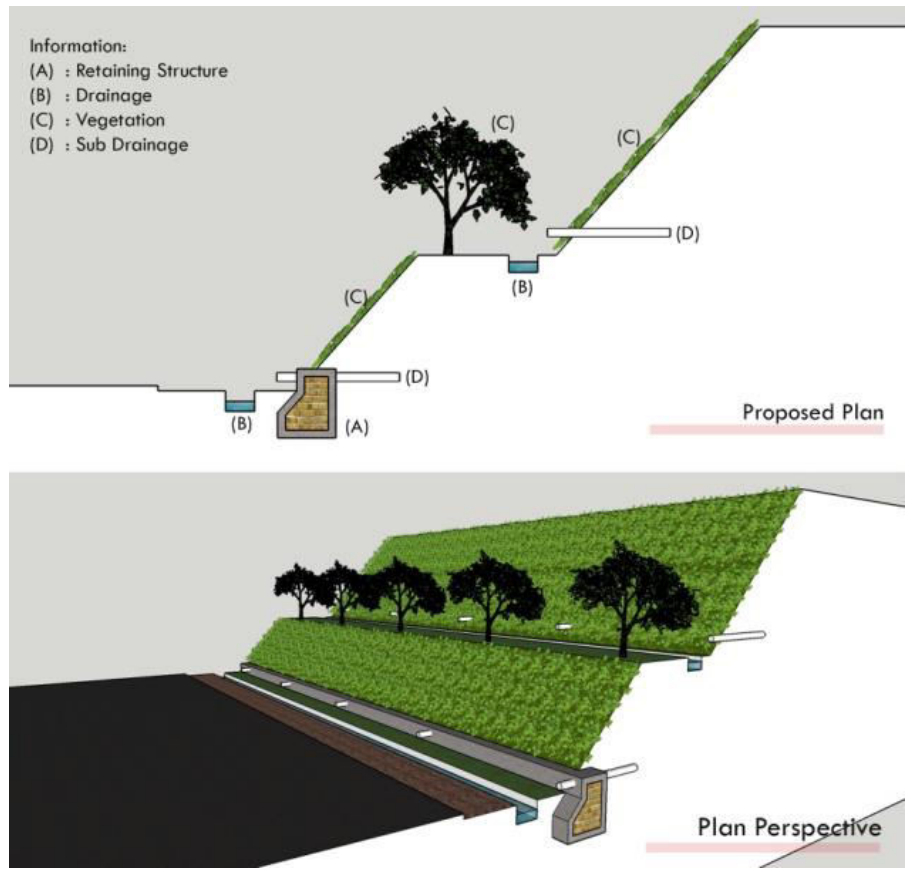

Fig. 2. Spatial arrangement proposed by the proposal (redraw from Zakaria, 2010)

Data from the proposal has been elaborated. a comparison between the data of this proposal and the factors causing landslides that have been mentioned earlier. There are 3 factors that are synchronous with the cause of landslides in precedents. There are an angle of slope, soil compositions, and rainfall. These factors are taken into account in designing landslide mitigation designs as mentioned above. The action that accounted as spatial arrangement on site that prone-area is the design to determine the slope safety by making the steps (terracing). Re-vegetation to control groundwater and rainwater for strengthening the slope with specific kind of crops. built drainage lining and subdrainage to control the degree of the soil saturation and control water distribution of the slope, and application of retaining wall at the bottom of slope for strength.

\subsubsection{Proposal of Settlement arrangement based on landslide mitigation, Parepare, 2015[25]}

Since the land is expensive and limited, some of the people of Capagallung choose to settle on the slopes of the hills which is consequently people are exposed to landslide disaster. The situation triggered a proposal to formulate settlements that consider the landslide mitigation aspect [25]. The concept of the settlement was formed based on landslide mitigation, in this proposal consider the analysis of physical and non-physical conditions, the condition of the structure of the house, and the surrounding environment. Physical conditions include: Slope conditions, there are 5 (five) categories, $29.95 \%$ flat, $14.40 \%$ sloping, $26.67 \%$ hill, $28.84 \%$ slopes, $4.14 \%$ steep slope. Further geological conditions, there are 3 (three) types of surface layers, consisting of mountainous rocks, alluvium rocks, and regosol. Rainfall in this area averages $2,275 \mathrm{~mm} /$ year or $189 \mathrm{~mm} / \mathrm{month}$, where the highest rainfall recorded in December is $378 \mathrm{~mm} /$ month.

The third is the condition of vegetation, dominated by mixed gardens spread at $8-40 \%$ altitude, with vegetation type, shrub, teak, mango tree, coconut tree, banana tree, and 
bamboo. Plants have the potential to prevent erosion. so it is necessary to increase the amount of vegetation that has the potential to prevent erosion such as teak trees and productive crops both in the home and in the environment, especially in slopes.

Land use is dominated by open space $58.11 \%$, settlement $24.73 \%$, and infrastructure $17.16 \%$. Last is to determine the level of erosion hazard based on a physical characteristic, using the USLE (Universal Soil Loss Equation) method, the following formula:

$$
\mathrm{A}=\mathrm{R} * \mathrm{~K} * \mathrm{LS} * \mathrm{CP}
$$

After obtaining the value of A (Erosion Rate), then calculated with TBE (Erosion potential).

$$
\mathrm{TBE}=\mathrm{A} / \mathrm{TSL}
$$

Based on the results of the analysis, for settlement $>45^{\circ}$ should be relocated because there is conservation planning, whereas the $0-45^{0}$ segment must be structurally rehabilitated. The following describes in detail the development of concepts:

1. Application of Terraces concept on slope $>10 \%-45 \%$.

2. Establish the proportion of cover and land (an average of $60 \%-40 \%$ ) as a facility to absorb water into the soil.

3. The direction of the drainage infrastructure is directed to roads, in the slope areas, the provision of absorption pore holes in every home.

4. Rainwater collection as a source of clean water.

5. Waste disposal system

6. Strengthening the soil with vegetation, consider of the distance and variety plant, so it will not burden the soil on the steep / slope area

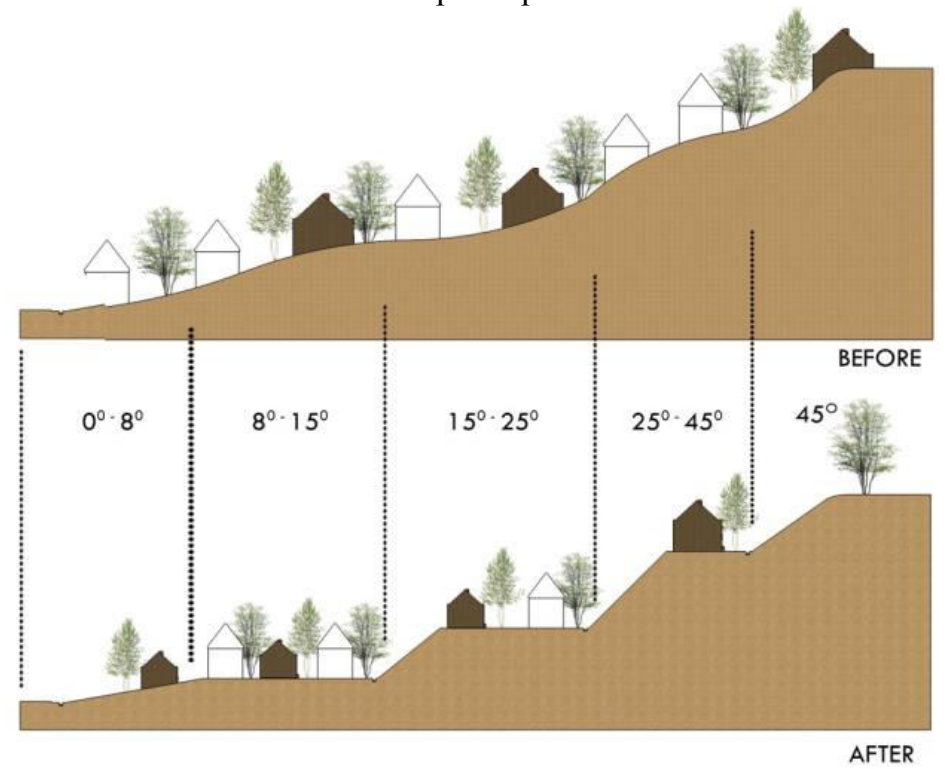

Fig. 3. Spatial arrangement proposed by the proposal (redraw based on Mandasari, Arifin, and Ali, 2016)

Data from precedence already discuss, and will be a comparison between the data of this precedence and the factors causing landslides that have been mentioned earlier, there are 4 factors that are synchronous with the cause of landslides in precedents. These factors are taken into account in designing landslide mitigation designs as mentioned above. There 
are an angle of slope, land used, soil composition, and rainfall, beside other factors, are mention. The other action, that accounted as spatial arrangement on the site is the application of terrace concept, establish the proportion of cover the land, drainage is directed to town drainage system, strengthening the soil with vegetation.

\subsection{Data Analysis}

One of the efforts is to understand disaster risk, consider a hazard, exposure, and vulnerability to disasters from a region [6]. As explained earlier, the occurrence of landslides was concluded from the previous research that there were 4 factors, which is angle of slope, land used, soil composition, and rainfall. That data will be compared with the vulnerability factors of an area described in the mitigation proposal, using typology analysis. According to Moneo [10], typology analysis there are 3 ways. One of them is to analyze the typology by finding a simple form of the basic properties. The following is described typology of landslide factors:

Table 1. Typology of landslide factor (author courtesy)

\begin{tabular}{|c|c|c|c|c|}
\hline \multirow{2}{*}{$\begin{array}{l}\text { Study Precedents of } \\
\text { Landslide Mitigation }\end{array}$} & \multicolumn{4}{|c|}{ The causes of landslides } \\
\hline & $\begin{array}{l}\text { Angle Of } \\
\text { Slope }\end{array}$ & Land Uses & $\begin{array}{c}\text { Soil } \\
\text { composition }\end{array}$ & Rainfall \\
\hline $\begin{array}{l}\text { Proposal for landslide } \\
\text { handling on the slopes } \\
\text { of toll road Gempol - } \\
\text { Pandaan km 51, } \\
\text { Pasuruan, East Java, } \\
2015\end{array}$ & $\sqrt{ }$ & $\sqrt{ }$ & $\sqrt{ }$ & $\sqrt{ }$ \\
\hline $\begin{array}{l}\text { Proposal of Starlet } \\
\text { Model, Proposed } \\
\text { Landslide Mitigation by } \\
\text { Approach of Region } \\
\text { Genetic Approach (case } \\
\text { study: Avalanche } \\
\text { Citatah, Padalarang, } \\
\text { East Java, 2010) }\end{array}$ & $\sqrt{ }$ & & $\sqrt{ }$ & $\sqrt{ }$ \\
\hline $\begin{array}{l}\text { Proposal of Settlement } \\
\text { arrangement based on } \\
\text { landslide mitigation, } \\
\text { Parepare, } 2015\end{array}$ & $\sqrt{ }$ & $\sqrt{ }$ & $\sqrt{ }$ & $\sqrt{ }$ \\
\hline
\end{tabular}

$\sqrt{=}$ Appeared

The occurrence of landslides was concluded from the previous research were 4 factors, after comparing with the vulnerability factors of an area described in the mitigation proposal, it was found that all four factors appeared in two reference, which is an angle of slope, land used, soil composition, and rainfall. The results found a tendency for regional vulnerability factors, it is in line with the aim of finding the vulnerability of an area to landslides [6], [7].

Referring to the effort of disaster management, there should be efforts to reduce disaster risk [6], [7]. In this section examines the typology of various mitigation proposals landslide disaster. this information serves as input in the effort of structuring mitigation strategy of landslides. According to Moneo [10], typology analysis there are 3 ways. One of them is to analyze the typology by knowing the function of an object, based on it and from several 
studies of precedent presented, obtained some equations in the design of landslide mitigation. the following is described Typology of landslide mitigation:

Table 2. Typology of landslide mitigation plan (author courtesy)

\begin{tabular}{|c|c|c|c|}
\hline \multirow[b]{2}{*}{ Proposal of Mitigation } & \multicolumn{3}{|c|}{ Proposal } \\
\hline & $\begin{array}{l}\text { Proposal for } \\
\text { landslide } \\
\text { handling on the } \\
\text { slopes of toll } \\
\text { road Gempol- } \\
\text { Pandaan KM } 51\end{array}$ & $\begin{array}{l}\text { Proposal of Starlet } \\
\text { Model, Proposed } \\
\text { Landslide } \\
\text { Mitigation by } \\
\text { Approach of } \\
\text { Region Genetic } \\
\text { Approach }\end{array}$ & $\begin{array}{c}\text { Proposal of } \\
\text { Settlement } \\
\text { arrangement } \\
\text { based on } \\
\text { landslide } \\
\text { mitigation }\end{array}$ \\
\hline \multicolumn{4}{|l|}{ Mitigation Step } \\
\hline \multicolumn{4}{|l|}{ - $\quad$ Preliminary Step } \\
\hline 1. Identification of the slope & $\sqrt{ }$ & $\sqrt{ }$ & $\sqrt{ }$ \\
\hline 2. Identification of soil types & $\sqrt{ }$ & $\sqrt{ }$ & $\sqrt{ }$ \\
\hline 3. Identification of moisture content & $\sqrt{ }$ & $\sqrt{ }$ & \\
\hline 4. Identification of rainfall & $\sqrt{ }$ & $\sqrt{ }$ & $\sqrt{ }$ \\
\hline 5. Stability Analysis of the slope & $\sqrt{ }$ & $\sqrt{ }$ & $\sqrt{ }$ \\
\hline $\begin{array}{l}\text { 6. Identification of } \\
\text { Vegetation }\end{array}$ & & $\sqrt{ }$ & $\sqrt{ }$ \\
\hline \multicolumn{4}{|l|}{ - $\quad$ Mitigation Planning } \\
\hline 1. Use of structural walls & $\sqrt{ }$ & $\sqrt{ }$ & \\
\hline 2. Use surface drainage & $\sqrt{ }$ & $\sqrt{ }$ & $\sqrt{ }$ \\
\hline 3. Undergrounds drainage & $\sqrt{ }$ & $\sqrt{ }$ & $\sqrt{ }$ \\
\hline 4. Vegetation of Slopes & & $\sqrt{ }$ & $\sqrt{ }$ \\
\hline 5. Concept of soil-terrace & $\sqrt{*}$ & $\sqrt{ }$ & $\sqrt{ }$ \\
\hline 6. Water Resistance Area & $\sqrt{ }$ & & \\
\hline 7. Basin Control & $\sqrt{ }$ & & \\
\hline $\begin{array}{l}\text { 8. Establish the proportion of land } \\
\text { cover }\end{array}$ & & & $\sqrt{ }$ \\
\hline 9. Absorption Pore & & & $\sqrt{ }$ \\
\hline
\end{tabular}

* according to existing slope

From the table above we can conclude that the process of structuring the mitigation strategy has 2 important parts, the first step is the preliminary step covering 6 points. 4 points such as identification of slope, soil type, rainfall, slope stability, is a step that often appears on 3 proposals of landslide mitigation disaster, it can be said that step is vital. by comparing the data from the proposal with the factors that caused the landslide mentioned earlier, a match was found. As for the identification of water content as well as the existing vegetation is an additional that must be considered, The results found a tendency for regional vulnerability factors, which are in line with the aim of finding the vulnerability of an area to landslides, and next used as a strategy for structuring mitigation plan.

The next step is mitigation planning covering 9 points. 3 planning points including surface drainage, Undergrounds drainage, and using terracing form is a step that often appears on 3 proposals for landslide mitigation. It can be said that the planning step is vital. While the points using the structural wall, slope vegetation, waterproof area, basin control, establish the proportion of land cover, and absorption pore, are the planning point to be considered. The results can be a trend of mitigation plan design, as an effort to determine the design of landslide mitigation. This is an effort to reduce the risk of disasters that will harm. 


\section{Conclusions}

Referring to $C R M S$ and $R A$ [6], [7], this paper has broadly accessed the vulnerability of landslides, as well as how to reduce disaster risks. The impact of the mitigation implementation is the spatial arrangement above and the change of structure of the land. re Typology of landslide and their factors are explored well as a part of the mitigation plan. It was found that all four factors of landslide-related to the angle of slope, the land use, the soil composition, and the rainfall areas the most trigger for regional vulnerability. The process of structuring the mitigation strategy has the two important parts which are the preliminary step concluding the identification of slope, soil type, rainfall, slope stability. The other mitigation planning concludes the three aspects of the surface drainage, the undergrounds drainage, and the use of the terrace. Also, the impact of spatial arrangement on site is significant since the certain places have their own properties related to the disaster management. With the terrace concept, surface and underground drainage, and application of a wall structure with vegetation of the site were also critical.

\section{Reference}

1. J. McGeown, "Bangladesh, Indonesia and Iran top natural disaster ranking - France, Italy, USA at 'high risk,"” 2010. [Online]. Available: https://reliefweb.int/report/bangladesh/bangladesh-indonesia-and-iran-top-naturaldisaster-ranking-france-italy-usa-high. [Accessed: 27-Jul-2018].

2. R. Tsujino, T. Yumoto, S. Kitamura, I. Djamaluddin, and D. Darnaedi, "History of forest loss and degradation in Indonesia," Land use policy, vol. 57, pp. 335-347, 2016.

3. BNPB, "Buku Capaian Kerja 2016," pp. 8-160, 2017.

4. M. Crozier, J and T. Glade, Landslide Hazard and Risk: Issues, Concepts and Approach in Landslides Hazard and Risk. John Wiley \& Sons Ltd, 2004.

5. D. Karnawati, "Bencana Alam Gerakan Massa Tanah di Indonesia dan Upaya Penanggulangannya,” J. Tek. Geol. UGM, 2005.

6. A. Baskoro and A. Riadi, "Menjaga Ketahanan Negara Terhadap Bencana Melalui Disaster Risk Management," crmsindonesia.org, 2018. [Online]. Available: http://crmsindonesia.org/publications/menjaga-ketahanan-negara-terhadap-bencanamelalui-disaster-risk-management/. [Accessed: 25-Jul-2018].

7. L. Kohler, Alois. Jülich, Sebastian. Bloemertz, Guidelines: Risk analysis - a Basis for Disaster Risk Management GTZ. GTZ, 2004.

8. [8] R. Shaw, H. Srinivas, and A. Sharma, Urban Risk Reduction: An Asian Perspective. Emerald Group Publishing Limited, 2009.

9. F. D. K. Ching, Architecture: Form, Space, and Order. Wiley, 2012.

10. R. Moneo, “On Typology Oppositions,” J. Idea Crit. Archit., no. Oppositions, pp. 2245, 1978.

11. W. D. Thornbury, Principles of Geomorphology. New York: John Wiley \& Sons Ltd, 1969.

12. D. Karnawati, "Mekanisme Gerakan Massa Batuan Akibat Gempabumi; Tinjauan Dan Analisis Geologi Teknik," Din. Tek. SIPIL, vol. Vol 7, pp. 179-190, 2007.

13. H. C. Hardiyatmo, Pemeliharaan Jalan Raya Perkerasan Drainase Longsoran. Yogyakarta: Gadjah Mada University Press, 2007.

14. I. I. Karlina, "Analisis Tingkat Kerawanan Longsor Pada Sebagian Jalan Kelas Iiic Di Sub-Das Gesing, Kabupaten Purworejo, Jawa Tengah,” J. Ris. Kebencanaan Indones., 
vol. Vol. 2, no. Kebencanaan, pp. 40-49, 2016.

15. Surono, "Potensi Bencana geologi di Kabupaten Garut," Pros. Semiloka Mitigasi, 2003.

16. A. Nursalim, M. Surmayadi, and A. Solihin, "Kajian Potensi Risiko Bencana Gerakan Tanah Di Kabupaten Majalengka, Jawa Barat," Pros. Pertem. Ilm. Tah. Ris. Kebencanaan, no. Membangun kemandirian Industrialisasi dan Teknologi Berbasis Riset Kebencanaan Indonesia, pp. 279-286, 2015.

17. H. Purwanto, E. Kusratmoko, and Sobirin, "Karakteristik Hujan Pemicu Longsor Berbasis Data Tropical Rainfall Measuring Missions (TRMM) (Studi Kasus Kabupaten Cianjur dan Kabupaten Garut)," Pros. Pertem. Ilm. Tah. Ris. Kebencanaan, no. Membangun kemandirian Industrialisasi dan Teknologi Berbasis Riset, pp. 258-266, 2015.

18. S. Arsyad, Konservasi Tanah dan Air. Bogor: IPB PRESS, 1989.

19. B. Mukti, Rifki, A. Susandi, M. Tamamadin, and D. Fajrin, Abdillah, "Pemetaan Potensi Daerah Rawan Longsor Di Provinsi Nusa Tenggara Barat Berbasis Sistem Informasi Geografi," Pros. Pertem. Ilm. Tah. Ris. Kebencanaan, no. ian Industrialisasi dan Teknologi Berbasis Riset, pp. 211-215, 2015.

20. Subandriyo, B. Santoso, Agus, S. Dwiyono, and Nurudin, "Evaluasi Sistem Pemantauan Gerakan Tanah; Prospek Menuju Sistem Peringatan Dini Yang Efektif," Pros. Pertem. Ilm. Tah. Ris. Kebencanaan, no. ian Industrialisasi dan Teknologi Berbasis Riset, pp. 200-210, 2015.

21. Hasnawir, "Intensitas Curah Hujan Memicu Tanah Longsor Dangkal Di Sulawesi Selatan (Rainfall intensity induced shallow landslides in South Sulawesi)," J. Penelit. Kehutan. Wallacea, vol. 1, no. 1, pp. 62-73, 2012.

22. R. Hidayat and A. Subiyantoro, "Penanganan Longsor Pada Lereng Jalan Tol Gempol - Pandaan Km 51, Pasuruan, Jawa Timur," J. Ris. Kebencanaan Indones., vol. Vol.1, pp. 15-22, 2015.

23. Z. Zakaria, "Model Starlet, suatu Usulan untuk Mitigasi Bencana Longsor dengan Pendekatan Genetika Wilayah (Studi Kasus: Longsoran Citatah, Padalarang, Jawa)," J. Geol. Indones., vol. Vol. 5, pp. 93-112, 2010.

24. Z. Zakaria, Permasalahan, Kebijakan dan Penanggulangan Bencana Tanah Longsor di Indonesia. 2004.

25. J. Mandasari, M. Arifin, and M. Ali, "Settlement Arrangement Based on Landslide Mitigation (Case Study: Capagallung, West Bacukiki District, City of Parepare)," Procedia - Soc. Behav. Sci., vol. 227, no. 22, pp. 442-450, 2016. 